\title{
PENYURATAN AWIG-AWIG DESA PAKRAMAN
}

\author{
Ketut Sudiatmaka \\ Jurusan Ilmu Hukum, Fakultas Hukum dan Ilmu Sosial \\ Universitas Pendidikan Ganesha Singaraja \\ Email : sudiatmaka@undiksha.ac.id \\ I Gusti Ayu Apsari Hadi \\ Jurusan Ilmu Hukum, Fakultas Hukum dan Ilmu Sosial \\ Universitas Pendidikan Ganesha Singaraja \\ Email : apsari.hadi@gmail.com
}

\begin{abstract}
ABSTRAK
Kebutuhan akan penyuratan awig-awig di desa pakraman didasari oleh peraturan-peraturan yang ada di lingkungan desa pakraman masih banyak dalam wujud tidak tertulis sementara perkembangan zaman yang mempengaruhi setiap lapangan kehidupan. Termasuk kehidupan di desa pakraman yang ada di Bali perlu adanya hukum dasar tertulis di tingkat desa yang berupa awig-awig. Perda Provinsi Bali No. 3 Tahun 2001 tentang Desa Pakraman Pasal 11 ayat (1) bahwa setiap desa pakraman menyuratkan awigawignya. Realisasi dari amanat Perda Bali tersebut maka dalam artikel ini akan lebih lanjut dibahas tentang bagaimana penyuratan awig-awig desa pakraman dipandang dari karakter hukum adat, baik sifat-sifat dan sistem hukum adat ?. Adapun penyuratan awig-awig dilakukan dilakukan melalui tahap (1) prakondisi yakni krama desa pakraman melalui prajuru desa melaksanakan pararem/kesepakatan bersama, guna menyampaikan aspirasi yang telah diserap dari masyarakat tentang keinginan penyuratan awig. Tahap (2) proses penyuratan awig/revisi awig yakni proses penyusunan awig yang menjadi bidang tugas panitia penyurat awig, lebih awal panitia menyusun jadwal kegiatan yang akan dilalui. Hal yang paling penting dalam penyuratan awig panitia akan memikirkan batas waktu menyuratkan dan mekanisme penentuan kesepakatan-kesepakatan yang dilandasi oleh rasionalitas, ilmiah, kebersamaan, hingga tanggung jawab moral pada Ida Sang Hyang Widhi. Hal akhir kemudian dilaksanakan pleno dan sosialisasi rancangan awig yang ditujukan pada masyarakat desa pakraman. Awig-awig yang telah disuratkan merupakan refleksi dari karakteristik nilai-nilai budaya yang tumbuh dan berkembang serta dijadikan pedoman pada masyarakat desa pakraman sejak zaman lampau sampai saat ini.
\end{abstract}

Kata Kunci : Penyuratan, awig-awig. 


\section{ABSTRACT}

The needed of awig-awig in pakraman village is based on the regulation in the life of desa pakraman is still have so many the unwritten form while the development of the age that affects every human life. Including life in pakraman village in Bali which is needs a basic written law at the village level called awigawig. Bali Provincial Regulation No. 3 of 2001 concerning Desa Pakraman Article 11 paragraph (1) that every pakraman village implies its awig-awig. The realization of the mandate of the Bali Regulation then this article will be discussed about how the dumping of awig-awig village pakraman viewed from the character of customary law, both traits and customary law system ? the awig-awig is done through stage (1) preconditions is the member/krama pakraman village through village prajuru implement pararem/agreement together, to convey the aspirations that have been absorbed from the community about the making of awig-awig. Stage (2) the awig/revision process of awig is the process of preaparing awig which is the task field of the awig committee, earlier the committee compiled a schedule of activities to be traversed. The most important thing in the writing of awig, the committee will be to think about the time limit set and the mechanism of determining the agreements based on rationality, scientific, togetherness, and moral responsibility to Ida Sang Hyang Widhi. The final thing the committee will be held a plenary and socialization of awig which drafted aimed to the pakraman village community. Awig-awig that has been written is a reflection of the characterisics of cultural values that grow and develop and be used as guidance on the pakraman village community since the past to present.

Keywords : the written, awig-awig.

\section{Pendahuluan}

Desa Pakraman atau yang sebelumnya bernama Desa Adat dalam eksistensinya memerlukan adanya peraturan-peraturan dasar guna memelihara ketertiban, kedamaian dan keseimbangan hidup di wilayah desa pakraman. Menurut Perda No 6 tahun 1986 menjelaskan bahwa, desa adat sebagai kesatuan masyarakat hukum adat dalam provinsi Daerah Tingkat I Bali. Selanjutnya dalam Perda No 3 Thun 2001 tentang desa pakraman menjelaskan bahwa, desa pakraman sebagai kesatuan masyarakat hukum adat di Provinsi Bali yang mempunyai satu kesatuan tradisi dan tata krama pergaulan masyarakat umat Hindu secara turun temurun dalam ikatan Kahyangan tiga atau Kahyangan desa yang mempunyai wilayah tertentu dan harta kekayaan sendiri serta berhak mengurus rumah tangganya sendiri.

Sejatinya desa pakraman sejak zaman lampau sudah memilki peraturan-peraturan hidup di lingkungan desa pakraman 
sekalipun sebagian besar bentuknya tidak tertulis. Seiring dengan waktu dan perkembangan zaman, peraturan-peraturan desa yang tidak tertulis dirasakan belum cukup memadai mengakomodasi kepentingan desa pakraman secara lebih luas. Menyikapi pekebeh jagat atau perkembangan dunia yang semakin mengglobal dan pengaruhnya kesegala lapangan kehidupan, termasuk kehidupan desa pakraman maka dirasa sangat perlu adanya hukum dasar tertulis di tingkat desa pakraman yang berupa awig-awig.

Kebutuhan akan adanya awigawig bagi desa pakraman mulai muncul pada tahun 1986, ketika itu, desa pakraman masih disebut desa adat. Secara yuridis formal kebutuhan tersebut tertuang dalam Perda Tingkat I Provinsi Bali Nomor 6 tahun 1986 tentang kedudukan, fungsi, dan peranan desa adat sebagai kesatuan masyarakat hukum adat dalam Provinsi daerah Tingkat I Bali. Pada pasal 7 ayat 1 Perda Nomor 6 tahun 1986 disebutkan, setiap desa adat agar memiliki awig-awig tertulis, dalam pasal 2 disebutkan awig-awig desa adat tidak boleh bertentangan dengan Pancasila, Undang-Undang Dasar 1945 dan peraturan perundang undangan lainnya. Perda Nomor 6 tahun 1986 selanjutnya diperbaharui menjadi Perda Bali Nomor 3 tahun 2001 tentang desa pakraman. Mulai tahun 2001 digunakan istilah desa pakraman, yang sebelumnya sudah digunakan pada awal terbentuknya desa di bali pada zaman Rsi Markandeya. Pasal 1 ayat 11 Perda Provinsi Bali Nomor 3 tahun 2001 tentang desa pakraman menyebutkan, awig-awig adalah aturan yang dibuat oleh krama desa pakraman dan atau krama banjar pakraman yang dipakai sebagai pedoman dalam melaksanakan Tri Hita Karana, sesuai dengan desa mawacara dan dharma agama desa pakraman/banjar pakraman. Pada pasal 11 ayat 1 Perda no 3 tahun 2001 menyebutkan, bahwa setiap desa pakraman menyuratkan awigawignya. Selanjutnya pada ayat 2 disebutkan, bahwa awig-awig desa pakraman tidak boleh bertentangan dengan agama, Pancasila, UndangUndang Dasar 1945 dan Hak Asasi Manusia.

Realisasi dari amanat Perda No 6 tahun 1986 pasal 7 (1) dan Perda No 3 tahun 2001 pasal 11 ayat 1 tersebut di atas, maka desa adat atau desa pakraman, mulai timbul upayaupaya masyarakat desa pakraman untuk menyusun atau menyuratkan peraturan-peraturan dasar yang ada di desanya dalam bentuk awig-awig desa pakraman. Sehubungan dengan itu, sangat diperlukan petunjuk teknis penyuratan awig-awig desa pakraman. Dalam penyuratan awigawig desa pakraman mestilah memperhatikan karakteristik dan nilai-nilai luhur yang timbul, tumbuh dan terpelihara pada masyarakat desa pakraman serta menjiwai kehidupan masyarakat 
desa pakraman. Atas dasar rasionalisasi esensial penyuratan awig-awig yang mesti mencermati karakteristik dan nilai-nilai luhur yang menjiwai masyarakat adat, maka penulis dalam paparan materi makalah ini akan membahas tentang bagaimana penyuratan awig-awig desa pakraman dipandang dari karakter hukum adat, baik sifat-sifat dan sistem hukum adat?

\section{Sifat-Sifat dan Sistem Hukum Adat}

Jauh sebelum hukum kolonial diterapkan di nusantara, masyarakat nenek moyang kita telah memiliki sistim hukum tersendiri. Sifat hukum nenek moyang kita yang sekarang dikenal dengan hukum adat sangat mengakomodir kebhinekaan bangsa Indonesia. Adapun yang menjadi karakteristik hukum adat adalah:

1. Sifat religious magis. Hukum adat sangat menjungjung nilai-nilai tradisional yang dijiwai oleh keyakinan akan kekuatan gaib yang dipelihara untuk menjaga kehidupan masyarakat yang aman dan tentram. Sifat religius dari hukum adat tampak dalam hal kesatuan batin, hubungan dunia lahir dan dunia gaib, adanya pemujaan pada arwah nenek moyang, ada upacara religious dalam setiap kegiatan, dan perbuatan-perbuatan lain terkait dengan kekuatan gaib.

2. Hukum adat mempunyai sifat komunalisti. Sifat ini tampak dalam hal hidup masyarakat adat mengelompok sebagai satu kesatuan yang utuh dan selalu mengutamakan kepentingan bersama, mempunyai sifat gotong royong, saling menghormati dan setiap orang sebagai bagian dari masyarakat adat dilengkapi dengan hak dan kewajiban untuk kepentingan bersama atau komunal.

3. Hukum adat bersifat demokratis. Sifat demokratis dari hukum adat dapat dilihat dari adanya karakter mengutamakan kepentingan bersama dan penyelesaian persoalan hidup dengan mengutamakan azas musyawarah mufakat. Hasil musyawarah akan ditaati oleh masyarakatnya.

4. Bersifat kontan. Hukum adat di Indonesia meyakini bahwa peralihan atau pemindahan hak dan kewajiban harus dilakukan pada saat yang bersamaan, artinya setiap serah terima jabatan atau kekuasaan dilakukan serentak, untuk menjaga keseimbangan di dalam kehidupan bermasyarakat.

5. Bersifat konkrit. Hukum adat di Indonesia meyakini bahwa ada tanda yang terlihat dalam setiap perbuatan hukum yang harus dinyatakan dengan benda yang berwujud. Tidak ada janji yang dibayar dengan janji, karena janji harus disertai dengan perbuatan nyata dan tidak ada kecurigaan diantara yang lain. 
Hukum adat juga mempunyai corak tradisional, keagamaan, kebersamaan, konkrit visual, terbuka dan sederhana, fleksibel, dinamis, tidak dikodifikasi, mengutamakan musyawarah mufakat.

Dalam penyuratan awig-awig, sifat-sifat dan corak hukum adat sangat penting diketahui dan diimplementasi dalam penyuratan awig-awig. Awig-awig yang nantinya dimiliki oleh masyarakat adat tidak menyimpang dari karakteristik dasar hokum adat.

\section{Nilai-Nilai Luhur Budaya Bali}

Masyarakat desa pakraman dalam tata krama pergaulan atau interaksi sosial di lingkungan desa pakraman senantiasa memperhatikan nilai-nilai hidup yang menjadi pedoman dan tuntunan di semua eksistensi kehidupannya. Nilai-nilai luhur yang sangat diagungkan, seperti adanya nilai dalam wujud idiologi Tri Hita Karana. Konsepsi TRI HITA KARANA baru dikenal tahun 1966, tepatnya pada tanggal 11 November 1966 pada saat konferensi Daerah Hindu Bali mengenai perjuangan / peran Hindu dalam pembangunan bali yang dihadiri oleh tokoh-tokoh masyarakat dan rohaniawan bali, dengan mengambil tempat di sekolah Dwijendra Denpasar. Idiologi TRI HITA KARANA mengandung nilai-nilai harmoni dan keseimbangan hidup lahir dan batin. Tri Hita Karana secara etimologi, artinya tiga penyebab kemakmuran. Tri Hita Karana memuat petunjuk hidup dan kehidupan harmoni yang membatin dan direfleksikan dalam pikiran, ucapan dan perbuatan. Tiga penyebab kemakmuran yang dimaksud adalah:

1. Parahyangan, makhluk religious krama desa pakraman sangat menjunjung hubungan harmoni dengan Sang Pencipta. Hubungan yang bersifat adiduniawi atau niskala adalah hubungan batin yang sangat dalam mendasari prilaku krama desa pakraman di mana pun. Tidak ada perbuatan benar apapun yang terlepas dari keyakinan untuk memohon kepada Sang Pencipta. Hubungan harmonis antara manusia dengan sang pencipta adalah jiwa krama desa pakraman. Itu sebabnya, dalam penyuratan awig-awig, nilai parahyangan menjadi nilai utama untuk diperhatikan.

2. Pawongan, sebagai mahluk sosial krama desa pakraman sangat menjungjung hubungan harmoni dengan sesamanya. Interaksi sosial sesama manusia terwujud dalam berbagai bentuk prilaku hidupnya. Yang paling menonjol adanya kebiasaan gotong royong dalam mengambil pekerjaan sebagai wujud cita-cita bersama, rasa memiliki, rasa partisipasi dan tanggung jawab dalam hidup kebersamaan. Pola hubungan kekerabatan, suka-duka selalu di dasari oleh filosophi hidup segalak-segilik, saluluk sebayantaka, paras paros sarpanaya. Intinya 
adalah harmonisasi dalam suka maupun duka.

3. Palemahan, sebagai mahluk yang menyatu dengan alam lingkungan, karma desa pakraman sadar betul bahwa kehidupannya tidak bisa lepas dengan lingkungan. Hubungan harmonis dengan alam lingkungan diyakini dapat memberikan dampak kedamaian, ketentraman dan kemakmuran. Krama desa pakraman wajib hukumnya menjaga harmonisasi dengan tumbuh-tumbuhan, hewan, dan segenap mahluk hidup yang signifikan memberikan maanfaat bagi hidupnya.

Demikianlah, penyuratan awigawig desa pakraman wajib memperhatikan Idiologi Tri Hita Karana. Bahkan idiologi ini menjadi landasan kearifan lokal utama yang harus tersirat dan tersurat di dalam awig-awig.

Selain idiologi Tri Hita Karana sebagai inti sari rohnya awig-awig, penyusunan awig perlu juga berpijak pada nilai-nilai luhur budaya bali seperti, nilai yang terkait dengan tujuan hidup menurut agama Hindu yaitu Moksartam Jagaddita ya caiti Dharma, nilai karma phala, nilai tat twam asi, paras-paros, nilai sagilik saguluk saluluk sebayantaka, nilai rwa bhinneda, catur purusartha, nilai satya wacana, nindihin patut, taksu, jengah, nilai ajaran catur paramita (Ardana. 2007: 64-65). Nilai-nilai positif yang juga patut dijadikan acuan penyuratan awig adalah nilai- nilai keagamaan seperti, bakti subakti, punia, meyadnya, suci nirmala, ngayah, ngiring widhi,sadhu budi/jujur. Nilai kemasyarakatan seperti, satia wacana, polos, lek kaucap jelek, jengah, ngandap kasor, puputan, dan nilai perarem (MPLA. 1990/1991:39).

\section{Proses Penyuratan Awig-Awig}

Penyuratan awig tidaklah mudah dan tidak sekali jadi, ada tahapan-tahapan yang harus dilalui sehingga penyuratan dapat mengakomodir pokok-pokok pikiran yang tumbuh dan hidup di tengah masyarakat adat. Penyuratan awigawig hendaknya memperhatikan Pancasila sebagai landasan idial, Undang-Undang Dasar 1945 sebagai landasan konstitusional dan Perundang-undangan lainnya sebagai landasan operasional. Selain mencermati kaedah-kaedah hukum tersebut di atas, penyusunan awig juga mestilah memperhatikan sifatsifat hukum adat, kearifan lokal Bali dalam bentuk idiologi Tri Hita Karana, demikian juga memperhatikan Dresta yang ada dan masih hidup, memperhatikan nilainilai budaya bali yang sudah terkenal adiluhung ke seluruh manca Negara.

Tahapan penyusunan awig-awig setidaknya ada tahapan pra kondisi, tahapan proses dan tahapan pengesahan serta pasupati awigawig.

1. Pada tahapan prakondisi penyusunan awig-awig, krama 
desa pakraman melalui prajuru desa pakraman perlu melaksanakan perarem, guna menyampaikan aspirasi yang telah diserap dari masyarakat pakraman mengenai keinginan penyuratan awig atau mungkin melakukan revisi awig. Apa itu perarem ? perarem berarti suatu kesepakatan bersama yang diputuskan dalam suatu paruman atau rapat mengenai sesuatu. Konsepsi perarem ini mempunyai nilai yang tinggi dalam kehidupan bersama di masyarakat. Perarem diambil atas dasar hasil musyawarah yang disebut mabligbag atau matatimbang dan di dalam musyawarah itu terdapat suatu sikap: ngeret budi (mengendalikan keinginan), paras-paros (tenggang rasa), tuwon (pertimbangan yang obyektif) yang semuanya dilandasi oleh asas kebersamaan dan asas kekeluargaan dalam arti sesama anggota masyarakat ( MPLA. 1990:39). Pada tahapan prakondisi prajuru desa pakraman menyampaikan dan sekaligus dimusyawarahkan dalam paruman mengenai keinginan penyuratan awig-awig atau revisi awig-awig. Selanjutnya prajuru desa memberi kesempatan pada peserta paruman untuk merespon keingin masyarakat adat untuk melakukan penyuratan/revisi awig. Ketika pikiran-pikiran krama tampak adanya kesepakatan untuk menyuratkan/merevisi awig maka prajuru desa memastikan kebulatan pendapat mereka. Apabila musyawarah sudah menyatakan kebulatan pendapat bahwa awig-awig perlu disuratkan atau direvisi bagi desa yang telah memiliki awig maka berikutnya prajuru menggali pemandangan umum peserta paruman mengenai bagaimana penyuratan awig/revisi awig dilakukan. Setelah itu, paruman memutuskan perarem mengenai perlunya penyuratan awig/revisi awig. Pada tahapan prakondisi berikutnya melalui paruman juga diminta kesepakatan pembentukan tim panitia penyuratan/revisi awig. Panitia penyuratan awig/revisi awig diperoleh dari hasil musyawarah paruman, tim panitia seyogyanya diupayakan representati mencerminkan semua unsur atau semua kelompok potensial dalam masyarakat adat. Ketika panitia sudah terbentuk maka prajuru desa menyerahkan penyuratan awig/revisi awig kepada tim panitia untuk melaksanakan tugasnya dengan pesan dari prajuru desa supaya tim panitia memperhatikan pokok pikiran masyarakat atau peserta paruman terutama mengenai pemandangan umum penyuratan awig/revisi awig yang diharapkan. Setelah prajuru melalui klian desa pakraman mengeluarkan Surat Keputusan 
tim panitia penyuratan awig / revisi awig maka tim panitia dapat mulai bekerja.

2. Tahap Proses Penyuratan Awig/Revisi Awig.

Pada tahap proses penyusunan awig yang menjadi bidang tugas panitia penyurat awig, lebih awal panitia menyusun jadwal kegiatan yang akan dilalui. Biasanya hal-hal pokok yang dijadwalkan adalah kegiatan matur piuning, pemandangan umum tokoh desa bersama panitia, mendiskusikan awig lain sebagai pembanding, pembagian kelompok yang membidangi Parhyangan, Pawongan dan Palemahan, Pengarahan dari kecamatan dan kabupaten, pembahasan dan penyuratan awig, pengesahan dan pasupati awig.

\section{Kegiatan Matur Piuning}

Pada kegiatan matur piuning panitia dapat mengundang prajuru desa pakraman dan tokoh-tokoh banjar adat yang ada di lingkungan desa pakraman. Matur piuning penting dilakukan mengingat awig yang disuratkan haruslah mengandung nilai religius cerminan karakter masyarakat adat. Dengan matur piuning ring sang meraga niskala, awig yang dihasilkan dapat memberikan keyakinan pada masyarakat pendukungnya. Upacara dan upakara pendukung disesuaikan dengan kebiasaan masyarakat adat setempat.

\section{Pemandangan Umum}

Guna memperoleh informasi yang lebih luas dan mengakomodasi pikiran-pikiran masyarakat adat mengenai awig yang representatif mewadahi kehendak masyarakat pendukungnya maka oleh tim panitia dilaksanakan paruman khusus melibatkan tokoh masyarakat adat yang tahu tentang masalah awig / hukum adat seperti, tetua yang berpengalaman di desa adat, para akademisi, para praktisi hukum bahkan jika perlu dapat mengundang Majelis Alit, Madia dan utama. Pada tahapan ini sangat penting, sebab pikiran-pikiran yang timbul akan diakomodir oleh panitia penyurat awig sehingga dapat diharapkan awig yang disuratkan tidak menyimpang dari landasan teoritis dan praktis. Pemandangan umum dari para pengelingsir masyarakat adat sangat penting agar ada keterkaitan kontinyuitas antara masa lalu, masa kini dan masa datang. Sedangkan akademisi dan praktisi pada pemandangan umum sangat penting guna memperoleh awig berkekuatan teoritika dan aplikatif. Formulasi dari hasil pemandangan umum menjadi perhatian dalam penyuratan awig.

\section{Mendiskusikan Awig Yang Menjadi Pembanding \\ Sekalipun panitia penyurat awig telah memperoleh berbagai masukan / informasi melalui pemandangan umum diseputar}


penyuratan awig dari pengelingsir, tokoh masyarakat, akademisi dan praktisi namun demikian masih diperlukan adanya upaya mempelajari awig-awig desa lain yang sudah jadi untuk memperoleh gambaran secara lebih detil mengenai materi awig dan sistimatika, demikian juga isi dari masing-masing sargah dan pawos sehingga awig yang tersurat mencakup totalitas kebulatan dari awal sampai akhir. Dari studi pustaka berupa awig yang sudah jadi, kita akan mengetahui bagaimana konsep Tri Hita Karana sebagai roh dari awig-awig sudah tersirat dan tersurat dalam awigawig. Awig yang akan disuratkan diharapkan benar-benar mewadai kepentingan desa pakraman. Namun demikian awig-awig tidaklah sama persis disusun menurut awig-awig desa lain. Awig-awig yang dimiliki nantinya, sungguh-sungguh adalah perujudan dari nilai-nilai, adat istiadat, budaya masyarakat adat itu sendiri. Jadi mendiskusikan awig yang dimiliki oleh desa lain dimaksudkan untuk mengetahui halhal prinsipil dalam penyusunan awig untuk paripurnanya awig yang akan disuratkan.

\section{Pembagian Kelompok Kecil Dalam Panitia Penyurat Awig}

Setelah memahami berbagai hal dalam penyuratan awig, panitia penyurat awig segera membentuk kelompok-kelompok khusus sesuai dengan kebutuhan pembahasan dan penyuratan masing-masing unsur yang menjadi isi dalam awig. Setidaknya ada tiga kelompok kecil yang bertugas membahas/mengkaji dan menyuratkan isi awig berkenaan dengan idiologi Tri Hita Karana. Artinya ada kelompok yang mengkaji dan menyuratkan isi awig yang menyangkut Parhyangan, disebut kelompok Parhyangan, demikian juga ada kelompok Pawongan dan kelompok Palemahan. Selain itu, perlu juga satu kelompok lagi yang mengkaji di luar tugas tiga kelompok di atas, yakni kelompok yang mengkaji dan menyuratkan isi awig bertalian dengan pembukaan awig dalam bentuk Murddha Citta dan Landasan, tujuan penyuratan awig. Murddha citta diformulasi oleh pengelingsir dan pakar serta tokok masyarkat adat. Merumuskan nilainilai dasar yang akan dituangkan dalam awig-awig, konstelasi batiniahnya haruslah tergambar dalam pembukaan awig atau Murddha Citta awig. Jadi murddha citta memuat nilai-nilai fundamental yang mengakomodasi kearifan lokal, nasional dan global serta parikrama pakibeh jagat yang tidak bisa dieleminir dari perkembangan zaman saat ini. Pada bagian murddha citta akan terlihat daya lentur atau fleksibelitas dari awig yang menggambarkan nilai Tri Hita Karana, nilai religious, humanistik, integralistik, demokrasi dan kesejahteraan masyarakat adat. 


\section{Pengarahan Dari Kecamatan Dan Kabupaten}

Meskipun desa pakraman

adalah desa tradisional yang otonom, akan tetapi perlu disadari bahwa desa pakraman dan desadesa tradisional lain di Indonesia berada di bawah Negara Kesatuan Republik Indonesia. Keadaan desa pakraman atau desa tradisional lain di Indonesia eksistensinya secara yuridis formal diakui oleh NKRI sepanjang masih ada, masih ada pendukungnya dan tidak bertentangan dengan NKRI. Rasionalitas eksistensi tersebut dengan tidak bermaksud menghilangkan sifat otonomi yang melekat pada desa pakraman, maka ketika penyuratan awig perlu adanya pembinaan dari kecamatan maupun kabupaten. Adapun perlunya pembinaan dilakukan agar awig-awig yang akan disuratkan tidak bertentangan dengan perundang-undangan Negara sebagai hukum positif. Dilihat dari logika perspektif hirarkis perundang-undangan, peraturanperaturan yang ada di wilayah NKRI tidak boleh bertentangan dengan landasan peraturan di atasnya. Pada landasan awig ada Pancasila, Undang-Undang Dasar 1945 dan Idiologi Tri Hita Karana. Landasan yang tercantum pada awig menunjukkan awig-awig tidak boleh bertentangan dengan Pancasila maupun Undang-Undang Dasar 1945. Oleh karena itu pembinaan dari pemerintah baik kecamatan maupun kabupaten menjadi bagian yang penting untuk diperhatikan.

\section{Inti Penyuratan Awig}

Setelah tahapan-tahapan proses penyuratan awig tersebut di atas, sampailah pada proses yang paling penting dan memerlukan waktu yang paling lama. Pada tahapan ini ketua panitia, sekretaris dan bendahara dan anggota perlu memikirkan batas waktu menyuratkan dan mekanisme penentuan kesepakatankesepakatan yang dilandasi oleh rasionalitas, ilmiah, kebersamaan, tanggung jawab pada diri sendiri, masyarakat serta tanggung jawab moral pada Ida Sang Hyang Widhi. Misalnya apakah batas waktu yang diberikan tiga bulan ?, enam bulan, atau berapa bulan? dan pertemuan penyuratan tiap berapa hari ? masyarakat desa adat yang multi profesi, biasanya waktu yang paling luwang adalah hari minggu. Jika logika itu sebagai dasar maka pertemuan dirancang tiap hari minggu. Kalau waktu yang dialokasikan adalah tiga bulan maka tahapan penyuratan memerlukan 12 kali pertemuan. Selanjutnya masingmasing kelompok diberi kesempatan melalui ketua kelompok kecil yaitu kelompok Parhyangan, Pawongan dan Palemahan untuk membahas dan menyuratkan masing-masing sargah, pawos yang menjadi bidang tugasnya. Di samping itu, ketua panitia penyurat awig juga menentukan batas 
Quorum dalam setiap waktu pembahasan dan penyuratan, ketua panitia juga perlu merancang pleno setelah kelompok kecil selesai penyuratan sesuai batas waktu. Pleno dimaksud adalah pleno di tingkat panitia penyurat awig. Mungkin perlu dipikirkan oleh panitia penyurat awig setelah pleno ditingkat panitia awig dilanjutkan dengan sosialisasi rancangan awig yang telah disuratkan oleh tim penyurat awig. Sosialisasi terutama ditujukan pada masyarakat desa pakraman untuk mendapatkan masukan-masukan penyempurnaan. Selain mendapatkan masukanmasukan penyempurnaan, sosialisasi juga dimaksudkan mendapatkan kekuatan legitimasi dari awig yang disuratkan. Apabila proses sosialisasi pada masyarakat adat telah dilakukan, maka tim panitia awig kembali melakukan pleno di tingkat panitia penyurat awig. Tujuan dari pleno di tingkat penyuratan awig pada bagian akhir penuratan adalah untuk membahas pokok-pokok pikiran yang timbul dan berkembang pada waktu dilakukan sosialisasi pada masyarakat desa pakraman. Pleno ini akan melakukan penyempurnaan final sebagai rancangan awig-awig desa pakraman sebelum disahkan dan dipasupati. Apabila sudah diyakini bahwa rancangan awigawig benar sudah final maka ketua panitia perlu menata penulisan awig apakah dengan huruf bali atau huruf latin atau huruf bali dan latin, apakah cukup dengan bahasa bali atau dwi bahasa yaitu bahasa bali dan Indonesia atau tiga bahasa yaitu bahasa Bali, Indonesia dan Inggris semua tergantung dari kebutuhan desa pakraman. Setelah itu selesai ketua panitia penyurat awig segera menyampaikan kepada klian desa adat terkait dengan waktu dan proses pengesahan dan pasupati awig-awig.

\section{Pengesahan Dan Pasupati Awig}

Menurut Perda TK I Bali tahun 1986 pada pasal 8 ayat 1 menyebutkan bahwa, awig-awig desa adat dibuat dan disahkan oleh krama desa adat. Dan ayat 2 menyebutkan bahwa, awig-awig desa adat dicatatkan di kantor bupati/wali kota madya kepala Daerah TK II yang bersangkutan. Pasal 12 ayat 1 Perda Provinsi Bali No. 3 tahun 2001 menyebutkan bahwa, awig-awig desa pakraman dibuat dan disahkan oleh krama desa pakraman melalui paruman desa pakraman. Dalam penjelasan pasal 8 Perda Provensi Bali No. 6 tahun 1986 dijelaskan bahwa, awigawig desa adat digarap oleh desa adat yang bersangkutan sampai dibentuk rancangan. Rancangan awig tersebut disampaikan kepada Bupati/wali kota madya kepala Daerah TK II yang bersangkutan untuk mendapatkan persetujuan. Setelah mendapat persetujuan Bupati/wali kota madya Kepala Daerah Tk II yang bersangkutan, barulah awig-awig desa adat 
tersebut disahkan oleh krama desa adat. Menurut Prof. Dr. Wayan P. windia, awig-awig mulai berlaku atau mengikat warga desa adat bersangkutan, setelah disetujui oleh warga desa dan kesobiahang/diumumkan dihadapan warga desa bersangkutan. Selain kesobiahang , sebagaimana biasanya dalam setiap menyelesaikan suatu pekerjaan, akan diakhiri dengan suatu upacara, yang dalam hal ini disebut sebagai upacara pasupati awig-awig (Windia. 1997:23). Selanjutnya Windia, menjelaskan ada beberapa hal yang harus dipersiapkan dalam pelaksanaan pasupati ini, antara lain :

1. Dimulai dari rapat perencanaan yang dipimpin oleh bendesa adat/. Dalam rapat ini dibicarakan tentang : (1). Penulisan awig dengan huruf bali dan huruf latin, termasuk penggandaannya.

Kemungkinan penyelenggaraan upacara pasupati secara tersendiri atau merangkaikan dengan penyelenggaraan upacara piodalan di pura tertentu. (3). Apakah pasupati akan dihadiri oleh bupati atau tidak. Bila bupati diharapkan hadir, jangan lupa mengadakan kordinasi dengan bagian hUkum kantor bupati setempat.

2. Setelah mantap rencana pelaksanaan pasupati, upacaranya segera dapat dilaksakan dengan rangkaian (1). Pasupati awig-awig dapat dilaksanakan

secara aederhana/nista, sedang/madya, besar/utama. Bila dipilih nista, maka upakaranya berupa sesayut pasupati dan pengurip-urip.. Kalau madya yang dipilih, akan terdiri atas sesayut pasupati, pengurip-urip, suci dan pejati. Sedangkan bila yang utama menjadi pilihan krama desa/warga desa, maka upakaranya lebih besar, yaitu : sesayut pasupati, suci, pejati, pangurip-urip, dan banten ayaban yang dapat dipilih salah satu diantara, dapetan, atau bebangkit.

3. Sambutan dari bupati, yang dilanjutkan dengan penandatangan awig-awig tertulis tersebut. Setelah proses pasupati selesai panitia penyurat awig-awig masih punya kuajiban mendaftarkan awig-awig tersebut di bagian hukum kantor bupati setempat. Menurut Perda Provinsi Bali No. 3 tahun 2001 pada pasal 12 ayat 2 disebutkan bahwa, awig-awig desa pakraman dicatatkan di kantor Bupati/wali kota masing-masing.

\section{PENUTUP}

Penyuratan awig-awig
sangatlah penting bagi desa
pakraman guna mewujudkan
masyarakat pakraman yang trepti,
damai, aman dan harmoni. Awig
disuratkan haruslah memperhatikan
landasan Idil, konstitusional dan
operasional. Penyuratan awig pada
tataran operasional dilandasi oleh
TRI HITA KARANA, dan


perundangan, dalam hal ini Perda TK I Provensi Bali No. 6 Tahun 1986 yang telah diperbaharui dengan Perda TK I Provensi Bali No. 3 Tahun 2001 tentang desa pakraman. Awig-awig yang disuratkan adalah refleksi atau pengejawantahan dari karakteristik dasar dan nilai-nilai budaya yang tumbuh dan berkembang serta terpelihara dan masih dijadikan pedoman kehidupan pada masyarakat desa pakraman, sejak zaman lampau sampai saat ini.

\section{Daftar Pustaka}

Ardika, Sutaba. 1997. Dinamika kebudayaan Bali. Denpasar: Upada Sastra

Ardana. 2007. Pemberdayaan kearifan lokal masyarakat Bali dalam menhadapi budaya global. Denpasar: pustaka Tarukan Agung.
Geriya. 2008. Transformasi Kebudayaan Bali. Surabaya: Paramita

MPLA. 1990/1991. Desa Adat Pusat Pembinaan Kebudayaan Bali. Denpasar: Proyek Pemantapan Lembaga Adat.

Pemda TK I Bali. 1997/1998. Himpunan Keputusan Seminar Kesatuan Tapsir Terhadap Aspek-Aspek Agama Hindu. Denpasar: Pemda TK I Bali

Suasthawa Dharmayuda. 1995. Kebudayaan Bali. Denpasar: kayumas Agung

Suasthawa Dharmayuda. 2001. Desa Adat. Denpasar: Upada Sastra

Sudiatmaka. 2005. Azas-Azas dan Murddha Hukum Adat Bali. Singaraja: undiksha Windia. 1997. Penuntun Penyuratan Awig-Awig. Denpasar: Upada Sastra 